\title{
Organic selenocyanates as halide receptors: from chelation to one- dimensional systems
}

\author{
Asia Marie S. Riel,,${ }^{\dagger \neq}$ Huu-Tri Huynh, ${ }^{\dagger}$ Olivier Jeannin, ${ }^{\dagger}$ Orion Berryman, ${ }^{\ddagger}$ and Marc Fourmigué $*, \dagger$ \\ ${ }^{\dagger}$ Univ Rennes, CNRS, ISCR (Institut de Sciences Chimiques de Rennes), UMR 6226, 35000 \\ Rennes, France \\ $¥$ Department of Chemistry and Biochemistry, University of Montana, 32 Campus Dr., Missoula \\ MT 59812, USA
}

\begin{abstract}
Organic selenocyanates were recently identified as strong chalcogen bond donors. They also play an important role in biochemistry. Here, we show that 1,2bis(selenocyanatomethyl)benzene $\mathbf{1}$ and 1,2,4,5-tetrakis(selenocyanatomethyl)-benzene $\mathbf{2}$ crystallize from DMF to afford solvates where two ortho $\mathrm{SeCN}$ moieties act as a chelate toward the carbonyl oxygen atom of DMF through strong Se••O chalcogen bonds. This result led us to explore their ability to also chelate halide anions $\left(\mathrm{Cl}^{-}, \mathrm{Br}^{-}\right)$in solution as well as in the solid state, an important issue in view of applications in crystal engineering or organocatalysis. NMR titration experiments provide an association constant between 1 and $\mathrm{Cl}^{-}$of $148 \mathrm{M}^{-1}$. We also observed the recurrent formation of cocrystal salts from the association of the ChB donors $\mathbf{1}$ and $\mathbf{2}$ with the onium salts $\mathrm{Ph}_{4} \mathrm{PCl}, \mathrm{Ph}_{4} \mathrm{PBr}$ and $\mathrm{Bu}_{4} \mathrm{NCl}$. We demonstrate that not only $\mu_{2}$-halide but also $\mu_{4}$ halide structures can be stabilized though $\mathrm{ChB}$ interactions, leading to the formation of complex polymeric anionic networks. Continuous shape measure calculations of these $\mu_{4}$-halide structures demonstrate that seesaw symmetry best describes the $\mu_{4}-\mathrm{Br}^{-}$bromide structures, while the smaller chloride anions tend to favor a close-to-tetrahedral $\mu_{4}-\mathrm{Cl}^{-}$organization, which is also confirmed by DFT calculations. Electrostatic surface potential calculations further demonstrate the efficiency of this chelating ortho-bis(selenocyanatomethyl) motif in $\mathbf{1}$ and $\mathbf{2}$, with $\mathrm{V}_{\mathrm{s} \text {, } \max }$ values reaching 50 $\mathrm{kcal} \mathrm{mol}^{-1}$, to be compared with the simplest benzyl selenocyanate $\left(36.4 \mathrm{kcal} \mathrm{mol}^{-1}\right)$ or the reference halogen bond donor $\mathrm{F}_{5} \mathrm{C}_{6}-\mathrm{I}\left(35.7 \mathrm{kcal} \mathrm{mol}^{-1}\right)$ in the same conditions.
\end{abstract}




\section{INTRODUCTION}

The study of the halogen bond (XB) in chemistry is currently developing very actively, with numerous implications in crystal engineering, catalysis, molecular materials or biochemistry. ${ }^{1,2}$ With similar characteristics to the $\mathrm{XB}$, the fields of chalcogen, pnictogen and tetrel bonding are also rapidly evolving. ${ }^{3}$ For example, properly activated chalcogen atoms ( $\left.\mathrm{S}, \mathrm{Se}, \mathrm{Te}\right)$ can, similarly to halogen atoms, exhibit $\sigma$-holes that facilitate a so-called chalcogen bond $(\mathrm{ChB})$ interaction with Lewis bases. Although a ChB has yet no formal definition, ${ }^{4}$ it can also be regarded as an attractive and directional noncovalent interaction between an electron-deficient chalcogen (partial positive) and an electron rich Lewis base (partial negative). Theoretical investigations show that in contrast to halogen atoms, ${ }^{5,6,7}$ the chalcogen atom can potentially provide two $\sigma$-holes, each of them along the $\mathrm{C}-\mathrm{Ch}$ bonds. Recent results show also that the situation is not that simple and that the location of the maximum $\left(\mathrm{V}_{\mathrm{s}, \max }\right)$ of the electrostatic surface potential (ESP) on the chalcogen atom can present large deviations from the $\mathrm{C}-\mathrm{Ch}$ bond axis. ${ }^{8}$ Because of these deviations and the emergence of two $\sigma$-holes, interaction predictability becomes more difficult and applications of $\mathrm{ChB}$ in crystal engineering are scarce. Many examples reporting $\mathrm{ChB}$ in crystalline compounds ${ }^{9}$ are essentially limited to "amphoteric" symmetric molecules having both $\mathrm{ChB}$ donor and acceptor moieties. Examples of these include the earlier structures of $\mathrm{Se}(\mathrm{CN})_{2}, \mathrm{Te}(\mathrm{CN})_{2}$ (Scheme 1a-b), ${ }^{10,11}$ telluradiazole derivatives (Scheme 1e) ${ }^{12,13}$ and selenophthalic anhydride (Scheme 1d). ${ }^{14}$ One efficient strategy to potentially favor one $\sigma$-hole over the other is to substitute the chalcogen atom with only one strong electron-withdrawing group (EWG), as for example with cationic imidazolium (Scheme 1h) or with nitrile substituents. In that respect, organic selenocyanates R$\mathrm{Se}-\mathrm{C} \equiv \mathrm{N}$ were shown to recurrently associate in the solid state through strong $\mathrm{Se} \bullet \bullet \mathrm{N} \equiv \mathrm{C}$ ChBs generating infinite one-dimensional motifs. ${ }^{15}$ Furthermore, their ability to form cocrystals upon interaction with Lewis bases was also demonstrated in the formation of 1:1 adducts between 1,3or 1,4-bis(selenocyanatomethyl)benzene and 4,4'-bipyridine, ${ }^{16}$ leading to the formation of heterochains similar to 1,3- or 1,4-diiodotetrafluorobenzene with the same ditopic 4,4'bipyridine. ${ }^{17,18}$ It should also be stressed that such organic selenocyanates have received wide attention for their biological activity. ${ }^{19,20,21}$ Their mode of action is not known but most probably involves a preliminary nucleophilic attack on the Se atom through intermediate ChB-stabilized adducts with the nucleophile. 

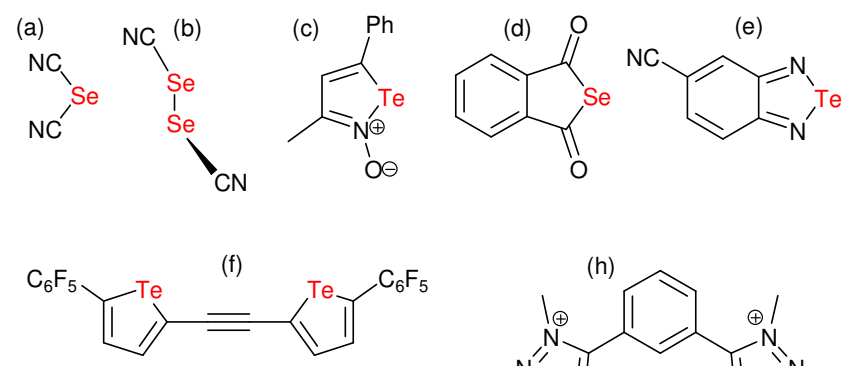

(g)
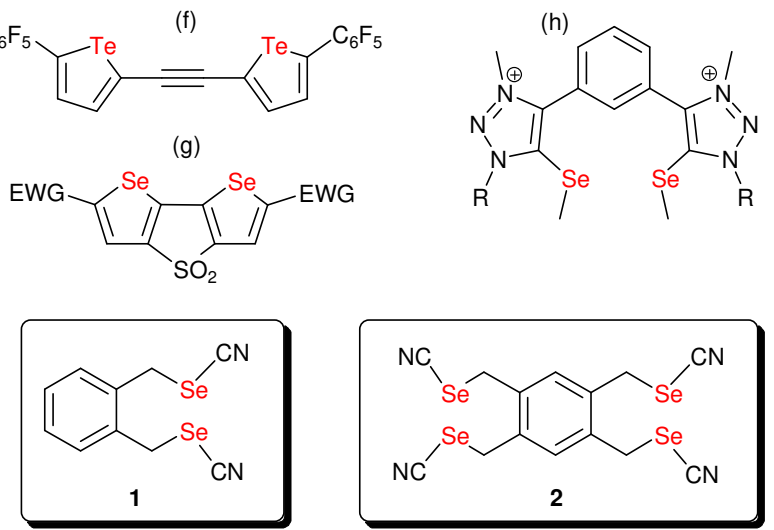

Scheme 1. Selected chalcogen bond $(\mathrm{ChB})$ donors

Besides neutral $\mathrm{XB}$ acceptors such as pyridines, $\sigma$-hole based interactions with halides has also been the subject of numerous investigations, as the XB interactions are reinforced through charge assistance..$^{22,23,24,25,26,27}$ A coordination chemistry of anions can thus be defined $28,29,30,31,32,33$, with coordination numbers up to eight, i.e. eight iodine or bromine atoms of $\mathrm{XB}$ donors around one single $\mu_{8}$-halide anion. A similar "coordination" chemistry of halides through $\mathrm{ChB}$ is still in its infancy. It has been originally evaluated only in solution from the evolution of the optical spectrum and/or the NMR signals of $\mathrm{ChB}$ donors such as dithienylthiophenes (Scheme $1 \mathrm{~g}$ ) ${ }^{34}$ or benzotelluradiazoles (Scheme 1e). ${ }^{35}$ The formation of the $\mu_{1^{-}}$or $\mu_{2}$-halide adducts, further rationalized through theoretical calculations, ${ }^{36,37}$ can be used for anion transport across lipid bilayers, ${ }^{38,39}$ a concept extended to oligodithienylthiophene derivatives. ${ }^{40}$ Also in solution, neutral rotaxanes incorporating SeMe moieties, as $\mathrm{ChB}$ donors, were used to reveal the local electronic environment of the chalcogen atoms in mechanically bonded rotaxane binding sites. ${ }^{41}$ Another important emerging application of $\mathrm{ChB}$ paralleling the work already reported with $\mathrm{XB}$ is catalysis. Indeed the dithienylthiophenes mentioned above were also used to activate the transfer hydrogenation of quinolines and imines, involving an initial step where the two conformationallylocked chalcogen atoms activate the pyridinic nitrogen atoms of the substrate. ${ }^{42}$ This work was further extended to another series of $\mathrm{ChB}$ donors, namely neutral benzodiselenazole derivatives. ${ }^{43}$ Similarly, in the solvolysis of benzhydryl bromide ${ }^{42,44}$ or 1 -chloroisochroman ${ }^{45}$ considered as 
halide abstraction benchmark reactions, $\mathrm{ChB}$ donors based on bis(benzimidazolium) cores accelerated reactions by a factor of 10-30 relative to the background reaction. Again here, the initial step is based on the interaction of the chalcogen with the electron-rich bromine or chlorine atoms.

It therefore appears at this stage that $\mathrm{ChB}$ interactions with halides, demonstrated from solution studies or theoretically investigated, are furthermore limited to $\mu_{1}$ - or $\mu_{2}$-halide motifs and have rarely been structurally identified and characterized. A CSD search based on non-bonding distances between halide anions $\left(\mathrm{Cl}^{-}, \mathrm{Br}^{-}, \mathrm{I}^{-}\right)$and selenium atoms provides only examples of selenium-containing cationic molecules. The only reported, crystallographically characterized examples which can be described as a neutral $\mathrm{ChB}$ donor interacting with halides is the association between selenocyanogen $\mathrm{NCSe}-\mathrm{SeCN}$ and $\mathrm{PhNMe}_{3}{ }^{+} \mathrm{Br}^{-}$to give the $\mu_{1}-\mathrm{Br}^{-}$complex, ${ }^{46}$ or very recently the association of 1,2,5-chalcogenadiazoles (Te, Se, S) with pseudo halides. ${ }^{47}$

As mentioned above, we recently reported that organic selenocyanates such as $\mathbf{1}$ and $\mathbf{2}$ (Scheme 1) crystallize with recurrent formation of chains stabilized through intermolecular Se••NC ChB interactions. Furthermore, recrystallization of $\mathbf{2}$ from DMF afforded a bis adduct where two neighboring SeCN moieties act as a chelate toward the carbonyl oxygen atom of DMF. We found (see below) that the very same process takes place with the ortho derivative 1 . We therefore considered that such ortho-substituted bis(selenocyanotomethyl) derivatives $\mathbf{1}$ or $\mathbf{2}$ could be well adapted to the chelation of halide anions, an interesting issue in view of their easy synthesis, and their possible applications in crystal engineering or organocatalysis (see above), as very recently reported by Bryce et al. from solution NMR and solid state studies. ${ }^{48}$

We report here on the formation of cocrystal salts from the association of the $\mathrm{ChB}$ donors 1 and 2 with the onium salts $\mathrm{Ph}_{4} \mathrm{PCl}, \mathrm{Ph}_{4} \mathrm{PBr}$ and $\mathrm{Bu} 4 \mathrm{NCl}$, demonstrating their ability to chelate halide anions though $\mathrm{ChB}$ interactions. Furthermore, we demonstrate here that not only $\mu_{2}$-halide but also $\mu_{4}$-halide structures can be stabilized though $\mathrm{ChB}$ interactions, leading to the formation of polymeric anionic networks. 


\section{RESULTS AND DISCUSSION}

The two $\mathrm{ChB}$ donors $\mathbf{1}$ and $\mathbf{2}$ were prepared from the reaction of the corresponding bromomethyl derivatives with $\mathrm{KSeCN}$, as described earlier. ${ }^{15}$ Recrystallization from DMF was shown to form the bis(DMF) adduct with $\mathbf{2}$, a similar monoadduct is obtained with $\mathbf{1}$. This solvate 1•DMF crystallizes in the monoclinic system, space group $\mathrm{P} 2{ }_{1} / \mathrm{a}$, with one molecule in the general position within the unit cell. As shown in Figure 1a and Table 1, the Se••O interaction is short: the reduction ratio (RR), defined as the ratio of the actual distance over the sum of van der Waals radii, amounts to 0.90 . Furthermore, the $\mathrm{C}-\mathrm{Se} \bullet \cdot \mathrm{O}$ angles are close to $180^{\circ}$ demonstrating the strong directionality of the interactions. The striking difference between the two DMF adducts is the relative conformation of the $\mathrm{SeCN}$ moieties relative to the aromatic plane. They adopt an anti

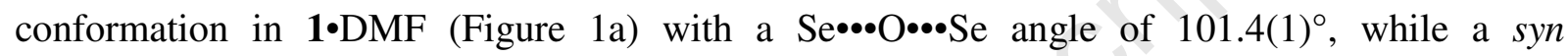

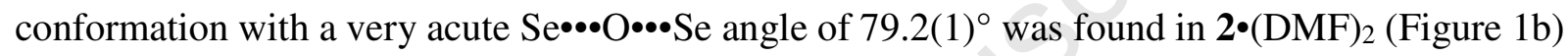
which brings the two Se atoms at van der Waals contact (3.75 $\AA$ ). These two DMF adducts demonstrate not only the ability of this motif to chelate but also its flexibility as it can adopt both syn and anti conformations, with an even stronger interaction in the syn conformation. The cocrystallization of $\mathbf{1}$ and $\mathbf{2}$ with tetraphenylphosphonium and tetrabutylammonium halides was therefore undertaken to evaluate their ability to also interact and chelate halide anions, with the added possibility to form extended one-dimensional motifs.

(a)

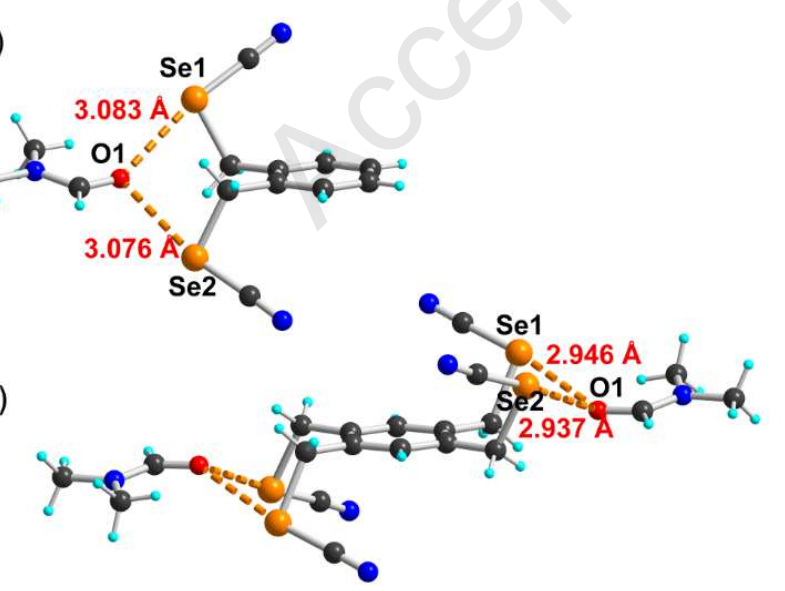

Figure 1. Detail of the DMF adducts, (a) 1•DMF, and (b) $2 \cdot(\mathrm{DMF})_{2}$. 
Table 1. Structural characteristics of the ChB interactions in the DMF adducts of $\mathbf{1}$ and $\mathbf{2}$.

\begin{tabular}{llllll}
\hline Conpound & Interaction & $\mathrm{Se} \bullet \bullet \mathrm{N}(\AA)$ & $\mathrm{RR}$ & $\mathrm{C}-\mathrm{Se} \bullet \bullet \mathrm{N}\left({ }^{\circ}\right)$ & Ref. \\
\hline $\mathbf{1 \bullet}(\mathrm{DMF})$ & $\mathrm{Se} 1 \bullet \bullet \mathrm{O}$ & $3.083(5)$ & 0.90 & $168.9(2)$ & this work \\
& $\mathrm{Se} 2 \bullet \bullet \mathrm{O}$ & $3.076(5)$ & 0.90 & $168.4(2)$ & \\
$\mathbf{2}(\mathrm{DMF})_{2}$ & $\mathrm{Se} 1 \bullet \bullet \mathrm{O}$ & $2.95(12)$ & 0.86 & $171.9(2)$ & 15 \\
& $\mathrm{Se} 2 \bullet \bullet \mathrm{O}$ & $2.94(5)$ & 0.86 & $175.2(2)$ & \\
\hline
\end{tabular}

Accordingly, $\mathbf{1}$ and $\mathbf{2}$ were associated with the chloride and bromide salts of $\mathrm{Ph}_{4} \mathrm{P}^{+}$and $n$ $\mathrm{Bu}_{4} \mathrm{~N}^{+}$as cations. Several co-crystal salts were obtained, with different stoichiometry, formulated as $(\mathbf{1})_{2} \bullet \mathrm{PPh}_{4} \mathrm{Cl} \bullet \mathrm{Et}_{2} \mathrm{O},(\mathbf{1})_{2} \bullet \mathrm{PPh}_{4} \mathrm{Br}, \mathbf{2} \bullet\left(\mathrm{PPh}_{4} \mathrm{Cl}\right)_{2}, \mathbf{2} \bullet\left(\mathrm{PPh}_{4} \mathrm{Br}\right)_{2}$, and $\mathbf{2} \bullet \mathrm{Bu} 4 \mathrm{NCl}$. Two other phases obtained in moist conditions and incorporating hydrogen-bonded water molecules, are formulated as $2 \bullet\left(\mathrm{PPh}_{4} \mathrm{Cl}\right)_{2} \bullet\left(\mathrm{H}_{2} \mathrm{O}\right)_{2}$ and $\mathbf{2} \bullet\left(\mathrm{PPh}_{4} \mathrm{Br}\right)_{2} \bullet\left(\mathrm{H}_{2} \mathrm{O}\right)_{2}$. They are isostructural and are described only in the ESI. The different structures can be separated into two groups, according to the actual number of selenium atoms around the halide anion. We will first describe $\mu_{2}$-halide structures analogous to those observed with neutral DMF, followed by the $\mu_{4}$-halide structures.

The $\mu_{2}$-halide chalcogen-bonded structures. $2 \bullet\left(\mathrm{PPh}_{4} \mathrm{Cl}\right)_{2}$ crystallizes in the triclinic $P \overline{1}$ space group, with the tetradentate $\mathrm{ChB}$ donor 2 on an inversion center, and $\mathrm{Ph}_{4} \mathrm{PCl}$ in the general position, hence the stoichiometry. As shown in Figure 2, two neighboring SeCN moieties interact with the $\mathrm{Cl}^{-}$anion through short and directional $\mathrm{ChB}$, providing a motif which differs from the DMF solvate by the anti orientation of the two SeCN moieties. Structural characteristics are collected in Table 2. Note that the chloride is otherwise surrounded only by hydrogen atoms at van der Waals contacts. This first example already demonstrates the flexibility of the $\mathrm{ChB}$ donors reported here, since in its $\mathrm{DMF}$ adduct, a syn orientation of the neighboring SeCN moieties was observed, in contrast with the anti orientation found here. Note also the $\mathrm{Se}_{1} \bullet \bullet \mathrm{Cl}^{-} \bullet \bullet \mathrm{Se}_{2}$ angle found here at $93.40(3)^{\circ}$, which is notably smaller than the angle found in the anti configuration of $\mathbf{1} \cdot \mathrm{DMF}$ (Figure 1a), a possible consequence of the slightly larger $\mathrm{Se} \cdot \bullet^{\cdot \mathrm{Cl}^{-}}$ distances when compared with the Se•••O ones. 


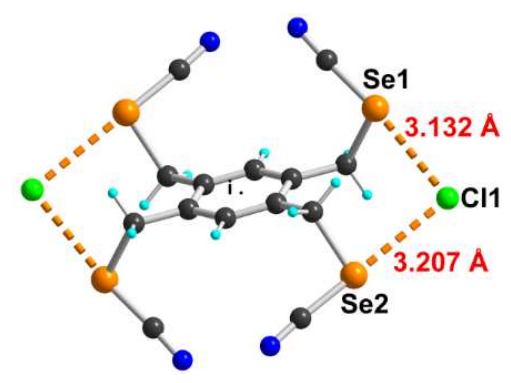

Figure 2. Detail of the interaction between $\mathbf{2}$ and $\mathrm{Cl}^{-}$in $\mathbf{2} \bullet\left(\mathrm{PPh}_{4} \mathrm{Cl}\right)_{2}$

Table 2. Structural characteristics of the $\mathrm{ChB}$ interactions in $\mu_{2}$-halide structures in the cocrystals salts with 2 . The ionic radii (rather than the van der Waals radii) were used for $\mathrm{Cl}^{-}(1.81 \AA)$ and $\operatorname{Br}^{-}(1.96 \AA)$.

\begin{tabular}{lllll}
\hline Compound & Interaction & $\mathrm{Se} \bullet \bullet \mathrm{Cl} / \mathrm{Br}(\AA)$ & $\mathrm{RR}$ & $\mathrm{C}-\mathrm{Se} \bullet \bullet \mathrm{Cl} / \mathrm{Br}\left(^{\circ}\right)$ \\
\hline $\mathbf{2 \bullet}\left(\mathrm{PPh}_{4} \mathrm{Cl}\right)_{2}$ & $\mathrm{Se}_{1} \bullet \bullet \mathrm{Cl}$ & $3.132(5)$ & 0.844 & $173.3(2)$ \\
& $\mathrm{Se}_{2} \bullet \bullet \mathrm{Cl}$ & $3.207(8)$ & 0.864 & $173.9(2)$ \\
$\mathbf{2 \bullet}\left(\mathrm{PPh}_{4} \mathrm{Br}\right)_{2}$ & $\mathrm{Se}_{1} \bullet \bullet \mathrm{Br}$ & $3.23(1)$ & 0.837 & $176.8(3)$ \\
& $\mathrm{Se}_{2} \bullet \bullet \mathrm{Br}$ & $3.25(1)$ & 0.842 & $174.6(3)$ \\
\hline
\end{tabular}

Unexpectedly, the analogous $\mathrm{Ph}_{4} \mathrm{PBr}$ bromide salt, albeit precipitating with the same stoichiometry, i.e. $\mathbf{2} \bullet\left(\mathrm{PPh}_{4} \mathrm{Br}\right)_{2}$, gives a completely different pattern. It crystallizes in the triclinic system, space group $P \overline{1}$, with the $\mathrm{ChB}$ donor molecule 2 on an inversion center and $\mathrm{PPh}_{4} \mathrm{Br}$ in the general position in the unit cell. As shown in Figure 3, the bromide is still interacting with two Se atoms but from two different $\mathrm{ChB}$ donor molecules 2, giving rise to complex anionic chains running along the crystallographic $a$ axis. However, structural characteristics of the $\mathrm{ChB}$ interactions (Table 2) are similar to those observed in the $\mathrm{Cl}^{-}$salt, with the only difference being the smaller $\mathrm{Se}_{1} \cdot \bullet \cdot \mathrm{Br}^{-} \bullet \cdot \mathrm{Se}_{2}$ angle at $83.44(3)^{\circ}$.

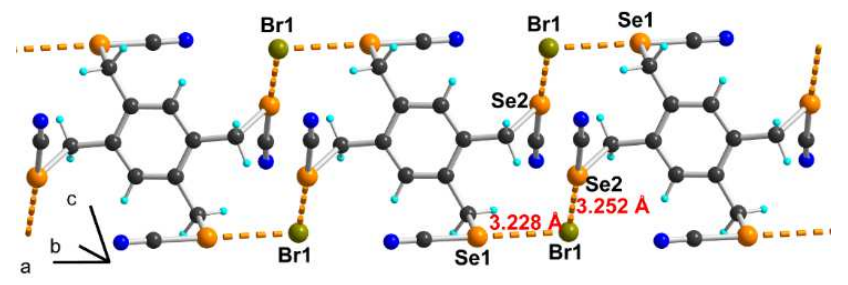

Figure 3. Detail of the $\mathrm{ChB}$ chains running along $a$ in $\mathbf{2} \bullet\left(\mathrm{PPh}_{4} \mathrm{Br}\right)_{2}$. 
The $\mu_{4}$-halide chalcogen-bonded structures. The tetraphenylphosphonium salts with the ortho-substituted $\mathrm{ChB}$ donor molecule $\mathbf{1}$ were isolated with a different stoichiometry than 2, i.e. $(\mathbf{1})_{2} \bullet \mathrm{PPh}_{4} \mathrm{Cl} \bullet \mathrm{Et}_{2} \mathrm{O}$ and $(\mathbf{1})_{2} \bullet \mathrm{PPh}_{4} \mathrm{Br}$, corresponding therefore to four $\mathrm{SeCN}$ group for each halide anion, i.e. a $\mu_{4}$-halide coordination. The $\mathrm{Cl}^{-}$salt $(\mathbf{1})_{2} \bullet \mathrm{PPh}_{4} \mathrm{Cl} \bullet \mathrm{Et}_{2} \mathrm{O}$ crystallizes in the monoclinic system, space group $\mathrm{P} 22_{1} / \mathrm{n}$, with two crystallographically independent $\mathrm{ChB}$ donor molecules 1, as well as the $\mathrm{PPh}_{4} \mathrm{Cl}$ in the general position in the unit cell, with an added $\mathrm{Et}_{2} \mathrm{O}$ molecule. The $\mathrm{Cl}^{-}$is interacting here with four selenium atoms through short and directional $\mathrm{ChB}$ contacts (Figure 4a, Table 3). One of the four $\mathrm{ChB}$ distances is slightly larger than the three others which compare to those found above in $\mathbf{2} \bullet\left(\mathrm{PPh}_{4} \mathrm{Cl}\right)_{2}$ where the $\mathrm{Cl}^{-}$anion was interacting with only two Se atoms. This dissymmetry might indicate either steric constraints which limits a complete four-fold coordination, or a weakening of the $\mathrm{ChB}$ interactions, as the monovalent chloride anion is now acting as $\mathrm{ChB}$ acceptor toward four rather than two $\mathrm{ChB}$ donors. This weakening is actually also observed in the bromide salts, as detailed below.

(a)

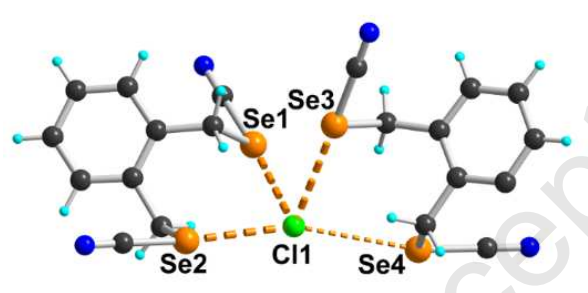

(b)

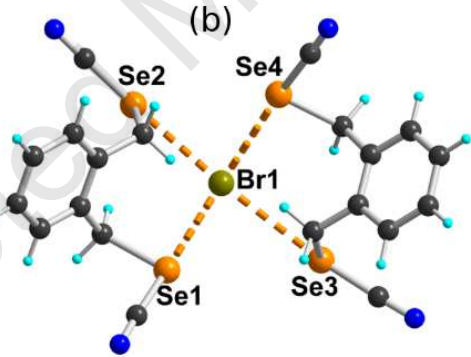

(c)

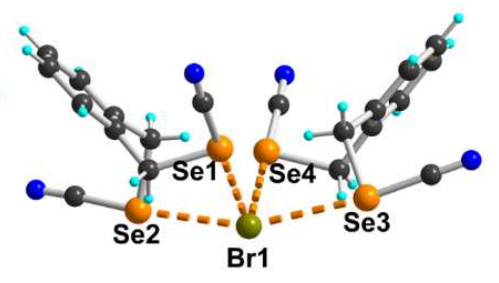

Figure 4. Detail of: (a) the $\mathrm{Cl}^{-}$and $(b, c)$ the $\mathrm{Br}^{-}$environment in the crystal structures of (a): $(\mathbf{1})_{2} \bullet \mathrm{PPh}_{4} \mathrm{Cl} \bullet \mathrm{Et}_{2} \mathrm{O}$ and $(\mathrm{b}, \mathrm{c}):(\mathbf{1})_{2} \bullet \mathrm{PPh}{ }_{4} \mathrm{Br}$ (orthorhombic phase). 
Table 3. Structural characteristics of the $\mathrm{ChB}$ interactions in $\mu_{4}$-halide structures in the cocrystals salts with 1 and 2 . The ionic radii (rather than the van der Waals radii) were used for $\mathrm{Cl}^{-}(1.81 \AA)$ and $\mathrm{Br}^{-}(1.96 \AA)$ while a van der Waals radius of $1.90 \AA$ was used for selenium.

\begin{tabular}{|c|c|c|c|c|}
\hline Compound & Interaction & $\mathrm{Se} \bullet \bullet \mathrm{Cl} / \mathrm{Br}(\AA)$ & RR & $\mathrm{C}-\mathrm{Se} \bullet \bullet \mathrm{Cl} / \mathrm{Br}\left(^{\circ}\right)$ \\
\hline \multirow[t]{4}{*}{$(\mathbf{1})_{2} \bullet \mathrm{PPh}_{4} \mathrm{Cl} \bullet \mathrm{Et}_{2} \mathrm{O}$} & $\mathrm{Se}_{1} \bullet \bullet \bullet \mathrm{Cl}$ & $3.188(2)$ & 0.859 & $172.6(2)$ \\
\hline & $\mathrm{Se}_{2} \bullet \bullet \bullet \mathrm{Cl}$ & $3.166(3)$ & 0.853 & $174.9(2)$ \\
\hline & $\mathrm{Se}_{3} \bullet \bullet \cdot \mathrm{Cl}$ & $3.220(3)$ & 0.868 & $179.2(3)$ \\
\hline & $\mathrm{Se}_{4} \bullet \bullet \cdot \mathrm{Cl}$ & $3.473(4)$ & 0.937 & $167.7(2)$ \\
\hline$(\mathbf{1})_{2} \bullet \mathrm{PPh}_{4} \mathrm{Br}$ & $\mathrm{Se}_{1} \bullet \bullet \cdot \mathrm{Br}$ & $3.363(3)$ & 0.871 & $177.48(1)$ \\
\hline \multirow[t]{3}{*}{ monoclinic phase } & $\mathrm{Se}_{2} \bullet \bullet \bullet \mathrm{Br}$ & $3.225(10$ & 0.835 & $174.86(1)$ \\
\hline & $\mathrm{Se}_{3} \bullet \bullet B r$ & $3.358(14)$ & 0.870 & $173.64(1)$ \\
\hline & $\mathrm{Se}_{4} \bullet \bullet \cdot \mathrm{Br}$ & $3.552(1)$ & 0.920 & $172.88(1)$ \\
\hline$(\mathbf{1})_{2} \bullet \mathrm{PPh}_{4} \mathrm{Br}$ & $\mathrm{Se}_{1} \bullet \bullet B r$ & $3.343(1)$ & 0.866 & $176.5(1)$ \\
\hline \multirow[t]{3}{*}{ orthorhombic phase } & $\mathrm{Se}_{2} \bullet \bullet B r$ & $3.186(1)$ & 0.825 & $175.4(1)$ \\
\hline & $\mathrm{Se}_{3} \bullet \bullet \bullet \mathrm{Br}$ & $3.346(1)$ & 0.867 & $171.9(1)$ \\
\hline & $\mathrm{Se}_{4} \bullet \bullet \bullet \mathrm{Br}$ & $3.459(1)$ & 0.930 & $172.6(1)$ \\
\hline \multirow[t]{4}{*}{$2 \cdot \mathrm{Bu}_{4} \mathrm{NCl}$} & $\mathrm{Se}_{1} \bullet \bullet \cdot \mathrm{Cl}$ & $3.176(3)$ & 0.856 & $173.9(2)$ \\
\hline & $\mathrm{Se}_{2} \bullet \bullet \cdot \mathrm{Cl}$ & $3.162(2)$ & 0.852 & $171.2(2)$ \\
\hline & $\mathrm{Se}_{3} \bullet \bullet \cdot \mathrm{Cl}$ & $3.220(4)$ & 0.868 & $174.7(3)$ \\
\hline & $\mathrm{Se}_{4} \bullet \bullet \cdot \mathrm{Cl}$ & $3.202(2)$ & 0.863 & $\mathrm{a}$ \\
\hline \multirow[t]{4}{*}{$\mathbf{2} \cdot \mathrm{Bu}_{4} \mathrm{NCl} \bullet(\mathrm{PhCN})_{0.5}$} & $\mathrm{Se}_{1} \bullet \bullet \mathrm{Cl} 1$ & $3.154(9)(\times 2)$ & 0.850 & $169.9(3)$ \\
\hline & $\mathrm{Se}_{2} \bullet \bullet \bullet C 11$ & $3.140(5)(\times 2)$ & 0.846 & a \\
\hline & $\mathrm{Se}_{3} \bullet \bullet \mathrm{Cl} 2$ & $3.092(5)(\times 2)$ & 0.833 & $173.0(3)$ \\
\hline & $\mathrm{Se}_{4} \bullet \bullet \bullet \mathrm{Cl} 2$ & $3.244(7)(\times 2)$ & 0.874 & $169.7(3)$ \\
\hline
\end{tabular}

a SeCN disordered on two positions

$(\mathbf{1})_{2} \bullet \mathrm{PPh}_{4} \mathrm{Br}$ was obtained as concomitant polymorphs, one crystallizing in the monoclinic $\mathrm{P} 2{ }_{1}$ space group, the other in the orthorhombic $\mathrm{P} 2{ }_{1} 2_{1} 2_{1}$ space group. A very similar motif is observed around the $\mathrm{Br}^{-}$anion (Figure $4 \mathrm{~b}$ and $4 \mathrm{c}$ ) in both polymorphs, which differ only by the relative organization of otherwise identical supramolecular layers (Figure S1 in ESI). The 
coordination geometry around the $\mathrm{Br}^{-}$is essentially the same in both phases (See Table 3). These structures provide the very first examples of an $\mu_{4}$-halide anion coordination through $\mathrm{ChB}$ donors. They are also characterized by a peculiar organization around the halide, with the four selenium atoms lying in the same hemisphere, with acute Se $\bullet X^{-} \bullet \bullet$ Se angles. Such geometries are in complete opposition to the classical metal coordination chemistry where overlapping interactions of the ligands orbitals with the $n d,(n+1) s$ and $(n+1) p$ orbitals of the metal center, together with the electron count, determines the favored coordination number and geometry, which favors structures where the ligands are farthest apart from each other. This concentration of the chalcogen atoms on one side of the halide, also observed in many instances in XB halide systems, might indicate that the formation of the first $\mathrm{XB}$ or $\mathrm{ChB}$ interactions with a halide anion, most probably polarizes it to such an extent that the remaining charge is concentrated at the proximity of the first $\mathrm{XB}$ or $\mathrm{ChB}$ donors, rather than opposite to them (see below).

The $\mu_{4}-\mathrm{X}^{-}$molecular structures obtained above with the bidentate $\mathrm{ChB}$ donor 1 let us infer that similar but polymeric $\mu_{4}$-halide structures should be obtainable from the tetradentate $\mathrm{ChB}$ donor 2. However, cocrystallizations of 2 with $\mathrm{PPh}_{4} \mathrm{Cl}$ or $\mathrm{PPh}_{4} \mathrm{Br}$ afforded only hydrated phases formulated as $\mathbf{2} \bullet\left(\mathrm{PPh}_{4} \mathrm{Cl}\right)_{2} \bullet\left(\mathrm{H}_{2} \mathrm{O}\right)_{2}$ and $\mathbf{2} \bullet\left(\mathrm{PPh}_{4} \mathrm{Br}\right)_{2} \bullet\left(\mathrm{H}_{2} \mathrm{O}\right)_{2}$ which still exhibit $\mu_{2}$-halide chalcogen-bonded motifs (See Figures S2, S3 and Table S1 in ESI). On the other hand, attempted cocrystallizations of 2 with the tetrabutylammonium salts $n$ - $\mathrm{Bu} 4 \mathrm{NCl}$ and $n$ - $\mathrm{Bu} 4 \mathrm{NBr}$ afforded crystalline phases with $n$ - $\mathrm{Bu} 4 \mathrm{NCl}$, actually as two concomitant phases, with one incorporating an extra benzonitrile solvent molecule, but both of them exhibiting these awaited $\mu_{4}-\mathrm{X}^{-}$structures (Figure 5). 2• $\mathrm{Bu} 4 \mathrm{NCl}$ crystallizes in the monoclinic system, space group $\mathrm{P} 22_{1} / \mathrm{c}$, with the tetradentate $\mathrm{ChB}$ donor $\mathbf{2}$ and the tetrabutylammonium salt in the general position in the unit cell. On the other hand, the $\mathrm{PhCN}$ solvate $\mathbf{2} \bullet \mathrm{Bu}_{4} \mathrm{NCl} \bullet(\mathrm{PhCN})_{0.5}$ crystallizes in the monoclinic system, space group $\mathrm{C} 2 / \mathrm{c}$, with the $\mathrm{ChB}$ donor 2 and the $\mathrm{Bu}_{4} \mathrm{~N}^{+}$cation in the general position and two crystallographically independent $\mathrm{Cl}^{-}$anions, each of them located on the two-fold axis along $b$. Note also that in both structures, one CN moiety is disordered over two close positions, with 50:50 occupancy, and that in $\mathbf{2} \bullet \mathbf{B u} 4 \mathrm{NCl} \bullet(\mathrm{PhCN})_{0.5}$, the $\mathrm{PhCN}$ molecule is disordered on an inversion center. Characteristic bond distances and angles associated with the $\mathrm{ChB}$ interactions are collected in Table 3. 

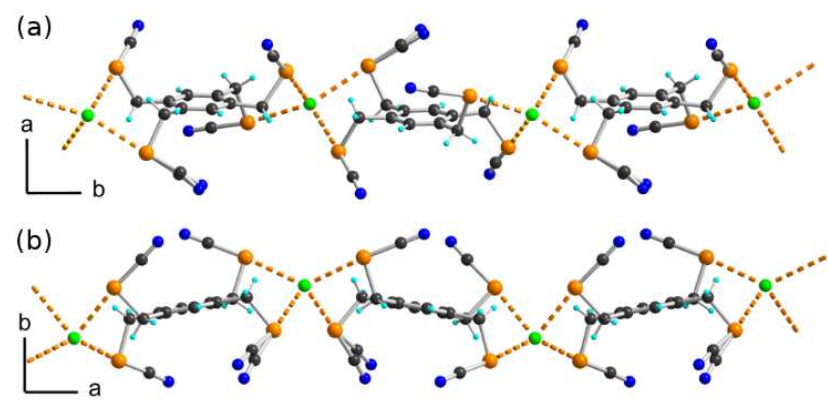

Figure 5. Detail of the chains incorporating the $\mu_{4}-\mathrm{Cl}^{-}$structures in (a) $\mathbf{2} \cdot \mathrm{Bu} 4 \mathrm{NCl}$, and (b) $\mathbf{2} \cdot \mathrm{Bu}{ }_{4} \mathrm{NCl} \bullet(\mathrm{PhCN})_{0.5}$. Cations and solvent molecules were omitted for clarity.

The six different $\mu_{4}-\mathrm{X}^{-}$molecular structures described above raise a question relative to the actual geometry around the halide anion. In classical coordination chemistry involving metallic cations at the coordination center, four-fold coordination is mostly represented by tetrahedral $\left(\mathrm{T}_{\mathrm{d}}\right.$ symmetry), and square planar ( $\mathrm{D}_{4 \mathrm{~h}}$ symmetry) geometries, with a general agreement that metal ions with a $\mathrm{d}^{8}$ electron configuration prefer the square-planar geometry, whereas $\mathrm{d}^{0}$ and $\mathrm{d}^{10}$ ions are essentially tetrahedral. Such rules are not expected to be obeyed here and indeed we see in Figure 6 that the six structures reported here vary between the tetrahedron and the so-called seesaw $\left(\mathrm{C}_{2 \mathrm{v}}\right)$ model geometries (Scheme 2), the latter being built from an octahedron with two vacant vertices. A quantitative measure of the proximity of a given geometry to model structures such as tetrahedral or square planar has been reported by Alvarez et al., ${ }^{49,50}$ based on the concept of continuous shape/symmetry measure. It is defined as the distance $S(G)$ of a molecular structure to the perfect polyhedron belonging to a symmetry point group $G$, with $0 \leq S(G) \leq 100$ with $S(G)=$ 0 for the perfect $G$ geometry. Analysis of the six structures shown in Figure 6 is reported in Table 4. We note that the smallest $S(G)$ values are actually found with the seesaw symmetry, which describes best the geometry of the $\mu_{4}-\mathrm{Br}^{-}$bromide structures, while the smaller chloride anions (and shorter Se $\bullet \cdot \mathrm{Cl}^{-}$distances) tend to favor a close-to-tetrahedral $\mu_{4}-\mathrm{Cl}^{-}$organization. 
(a)

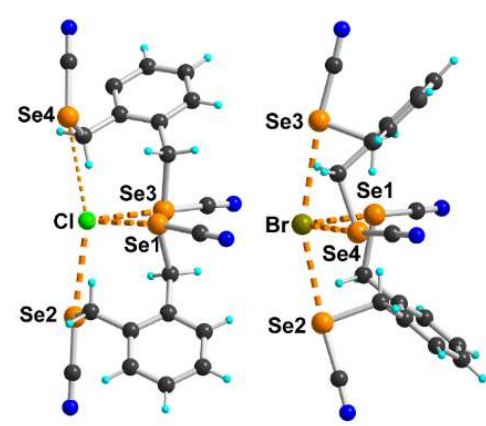

(c)

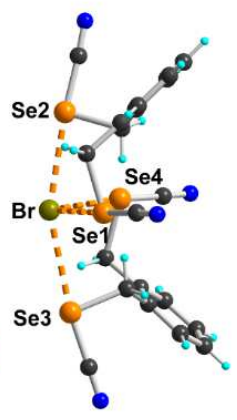

(d)

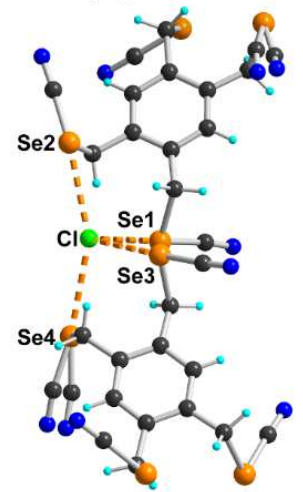

(e)

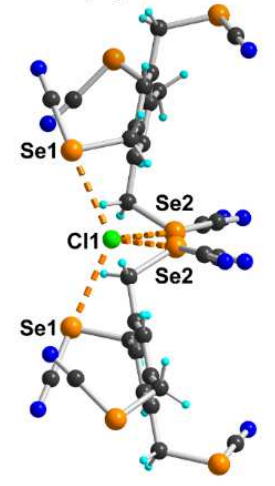

(f)

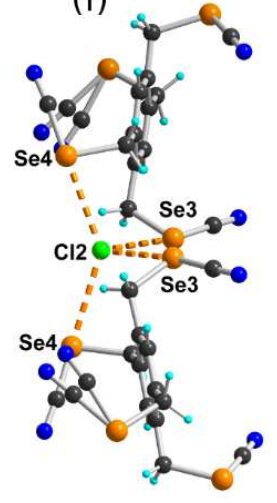

Figure 6. Detail of the $\mu_{4}-\mathrm{X}^{-}$molecular structures in: (a) (1) $)_{2} \bullet \mathrm{Ph}_{4} \mathrm{PCl}$, (b) (1) $)_{2} \bullet \mathrm{Ph}_{4} \mathrm{PBr}$, monoclinic phase, (c) $(\mathbf{1})_{2} \bullet \mathrm{Ph}_{4} \mathrm{PBr}$, orthorhombic phase, (d) $\mathbf{2} \bullet \mathrm{Bu} 4 \mathrm{NCl}$, (e) $\mathbf{2} \cdot \mathrm{Bu}_{4} \mathrm{NCl} \bullet(\mathrm{PhCN})_{0.5}$ around $\mathrm{Cl}(1)$, (f) $\mathbf{2} \bullet \mathrm{Bu}_{4} \mathrm{NCl} \bullet(\mathrm{PhCN})_{0.5}$ around $\mathrm{Cl}(2)$.

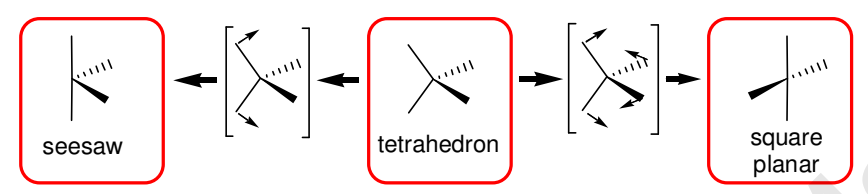

\section{Scheme 2}

Preliminary DFT structure optimizations were performed on the $\mu_{4}-\mathrm{X}^{-}$molecular structures found in $(\mathbf{1})_{2} \bullet \mathrm{Ph}_{4} \mathrm{PCl}$ and $(\mathbf{1})_{2} \bullet \mathrm{Ph}_{4} \mathrm{PBr}$ in order to determine a minimal energy geometry (in the gas phase). Starting from the experimental geometry without any constraint led to a minimal energy structure very close to the tetrahedral one (Table 4) for both the chloride and the bromide derivatives. On the other hand, constraining the structures to a square-planar geometry during optimization was unsuccessful, and calculations did not converge. 
Table 4. Continuous shape measure calculations giving the $S(G)$ distance of the geometry of the six different $\mu_{4}-\mathrm{X}^{-}$molecular structures shown in Figure 6 to three ideal geometries (See Table S2 in ESI for details).

\begin{tabular}{lccc}
\hline$\mu_{4}-\mathrm{X}^{-}$structure & seesaw & tetrahedron & square-planar \\
\hline$(\mathbf{1})_{2} \cdot \mathrm{Ph}_{4} \mathrm{PCl}$ & 1.90 & 7.09 & 27.66 \\
$(\mathbf{1})_{2} \bullet \mathrm{Cl}^{-}($DFT-optimized $)$ & 6.99 & 1.71 & 24.25 \\
$(\mathbf{1})_{2} \cdot \mathrm{Ph}_{4} \mathrm{PBr}$ monoclinic & 3.24 & 17.40 & 9.83 \\
$(\mathbf{1})_{2} \cdot \mathrm{Ph}_{4} \mathrm{PBr}$ orthorhombic & 3.34 & 17.44 & 9.67 \\
$(\mathbf{1})_{2} \bullet \mathrm{Br}^{-}($DFT-optimized $)$ & 7.33 & 2.61 & 23.75 \\
$\mathbf{2} \cdot \mathrm{Bu}{ }_{4} \mathrm{NCl}$ & 2.03 & 5.45 & 26.16 \\
$\mathbf{2} \cdot \mathrm{Bu} 4 \mathrm{NCl} \bullet(\mathrm{PhCN})_{0.5}$ & & & \\
around $\mathrm{Cl}(1)$ & 5.95 & 2.42 & 27.56 \\
around $\mathrm{Cl}(2)$ & 4.98 & 4.81 & 28.19 \\
\hline
\end{tabular}

\section{Solution NMR studies of the complexation}

In order to further investigate the ability of such selenocyanate derivatives to interact with halide anions, we have performed ${ }^{1} \mathrm{H}$ NMR titrations, where increasing quantities of tetraethylammonium chloride were added to a $0.016 \mathrm{M}$ solution of 1 in $\mathrm{CDCl}_{3}$. The $\mathrm{CH}_{2}$ proton singlet resonance exhibits a downfield shift, up to $\Delta \delta=0.19 \mathrm{ppm}$ after addition of $4 \mathrm{Cl}^{-}$equivalents (Fig S4 in ESI). On the other hand, the signals of the aromatic protons are upfield shifted and split into a complex signal. Based on the methylenic protons, an association constant $K_{a}$ of 148(1) for the 1:1 complex was determined with the WinEQNMR2 ${ }^{51}$ program (Fig S4). This value can be compared with those reported earlier, for example in cationic chelating bis-triazolium derivatives bearing $\mathrm{SeMe}$ substituents with $\mathrm{K}_{\mathrm{a}}=652(13)$ in $\mathrm{CD}_{3} \mathrm{CN},{ }^{52}$ or in neutral bis(2-tellurophene)acetylene derivative with $\mathrm{K}_{\mathrm{a}}=111 \mathrm{M}^{-1}$ in acetone. ${ }^{34}$

Electrostatic surface potentials (ESP). The different $\mu_{2}-\mathrm{X}^{-}, \mu_{4}-\mathrm{X}^{-}$structures and NMR studies unambiguously demonstrate the ability of such simple organic selenocyanates to act as chelating $\mathrm{ChB}$ donors toward halide anions. Tables 2 and 3 illustrate that the Se $\bullet \bullet \mathrm{X}^{-}$distances and $\mathrm{C}-\mathrm{Se} \bullet \bullet \mathrm{X}^{-}$angles represent strong and directional interactions, with reduction ratio (RR) down 
to 0.83 , with $\mathrm{Cl}^{-}$and $\mathrm{Br}^{-}$anions. The ability of such ortho-substituted derivatives $\mathbf{1}$ or $\mathbf{2}$ to interact with halides can be also rationalized with calculations of the electrostatic surface potentials (ESP) of the $\mathrm{ChB}$ donors. As shown in Figure $7 \mathrm{a}$ for the simplest monodentate benzylselenocyanate molecule $(\mathrm{BzSeCN})$, a $\sigma$-hole is indeed generated in the prolongation of the $\mathrm{NC}-\mathrm{Se}$ bond, with a $\mathrm{V}_{\mathrm{s}, \max }$ value of $36.4 \mathrm{kcal} \mathrm{mol}^{-1}$. This $\mathrm{V}_{\mathrm{s}, \max }$ value of $36.4 \mathrm{kcal} \mathrm{mol}^{-1}$ in $\mathrm{BzSeCN}$ can be also compared with that found, for example, in the prototypical $\mathrm{C}_{6} \mathrm{~F}_{5}-\mathrm{I} \mathrm{XB}$ donor in the same calculation conditions, namely $35.7 \mathrm{kcal} \mathrm{mol}^{-1}$. This further demonstrates that the $\mathrm{R}-\mathrm{SeCN}$ selenocyanate motif not only exhibits the directionality but also the strength of well-established XB donors. As shown in Figure 7b, when moving from this monodentate benzylselenocyanate to the bidentate $\mathrm{ChB}$ donor $\mathbf{1}$ in its anti conformation the $\sigma$-holes of both selenium atoms merge into a broad electron-deficient zone characterized by a much larger $\mathrm{V}_{\mathrm{s}, \max }$ value than in $\mathrm{BzSeCN}$, namely $48.3 \mathrm{kcal} \mathrm{mol}^{-1}$. The same calculations performed on the syn conformation of the bidentate ChB donor 1 (Figure 7c) similarly provide a broad electron-deficient zone, with an even larger $\mathrm{V}_{\mathrm{s}, \max }$ value, namely $51.5 \mathrm{kcal} \mathrm{mol}^{-1}$. These striking results explain the efficiency of molecules such as $\mathbf{1}$ or $\mathbf{2}$ to chelate halide anions. They indeed combine adapted geometrical requirements for chelation with a strongly enhanced electrostatic interaction. They differ in that respect from the many reported chelating systems based on $X B$ interactions ${ }^{2}$ where halogen atoms are always far apart from each other and do not exhibit such a strong cooperative effect. Similar calculations performed on the tetradentate $\mathrm{ChB}$ donor 2 (in its anti and its syn conformations) give a symmetric picture (Figures S5, S6 in ESI) with two identical, cooperatively enhanced electron-deficient zones with a similarly large $\mathrm{V}_{\mathrm{s} \text {,max }}$ values of 50.2 and $54.6 \mathrm{kcal} \mathrm{mol}^{-1}$, respectively. 
(a)
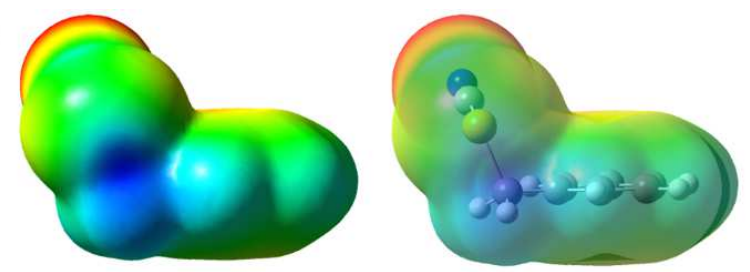

(b)
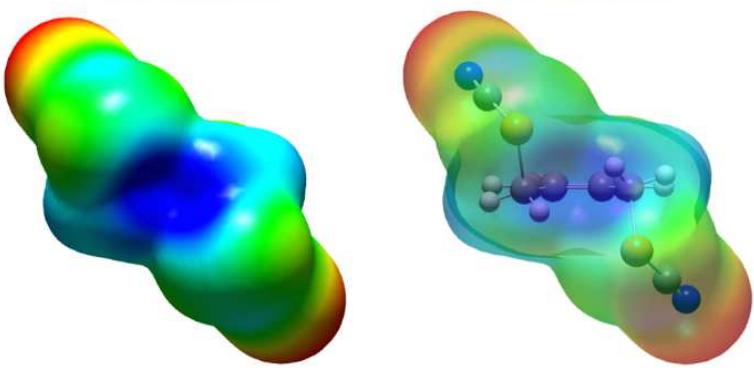

(c)
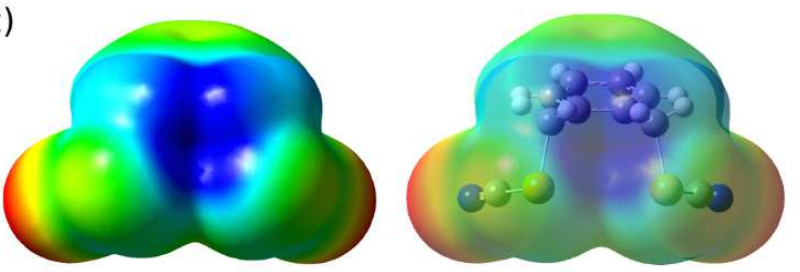

Figure 7. Computed electrostatic potential on the 0.001 a.u. isodensity surface of: (a) benzylselenocyanate $\mathrm{BzSeCN}$, (b) 1,2-bis(selenocyanatomethyl)benzene 1 in anti conformation, (c) 1,2-bis(selenocyanatomethyl)benzene 1 in syn conformation. Potential scale ranges from -25 $\mathrm{kcal} \mathrm{mol}^{-1}$ to $38 \mathrm{kcal} / \mathrm{mol}^{-1}$.

\section{CONCLUSIONS}

This work provides strong evidence that organic selenocyanates can indeed interact with halide anions in the solid state to form anionic isolated or extended 1D motifs, based on recurrent $\mu_{2-}$ or $\mu_{4}$-halide structures. The $\mu_{2}$-halide chalcogen-bonded motifs are characterized here with acute Se $\bullet X^{-} \bullet \bullet$ Se angles $\left(<90^{\circ}\right)$, while the $\mu_{4}$-halide chalcogen-bonded motifs adopt preferentially the so-called seesaw geometry with $\mathrm{Br}^{-}$, and close-to-tetrahedral geometry with $\mathrm{Cl}^{-}$. Both molecules $\mathbf{1}$ and $\mathbf{2}$, with two neighboring SeCN moieties acting as a pincer, either in syn or anti conformation, generate a broad electron-deficient zone characterized by very large $V_{\mathrm{s}, \max }$ values of $48-52 \mathrm{kcal}$ mol $^{-1}$ (calculated on the 0.001 a.u. isodensity surface). Shift of solution NMR signals of 1 with increasing amounts of chloride anion confirm the sizeable interaction with a association constant of $148 \mathrm{M}^{-1}$, demonstrating that such compounds are particularly well suited to act as halide 
receptors - a very promising property in light of their involvement in organocatalyzed reactions as well as in biological processes.

\section{EXPERIMENTAL SECTION}

Synthesis. 1,2-bis(selenocyanatomethyl)benzene (1) and 1,2,4,5-tetrakis (selenocyanatomethyl) benzene (2) were prepared as previously described. ${ }^{53,15}$ Recrystallization of $\mathbf{1}$ from DMF with $\mathrm{Et}_{2} \mathrm{O}$ layering afforded the $\mathbf{1} \cdot \mathrm{DMF}$ solvate as colourless crystals.

\section{Crystal growth}

2•( $\left.\mathrm{Ph}_{4} \mathrm{PCl}\right)_{2}$. In a small tube, $2(16.1 \mathrm{mg}, 0.029 \mathrm{mmol})$ and $\mathrm{Ph}_{4} \mathrm{PCl}(25.1 \mathrm{mg}, 0.067 \mathrm{mmol}$, 2 equiv) were dissolved in dry benzonitrile $(2 \mathrm{~mL})$ at $60^{\circ} \mathrm{C}$. After cooling, the solution was layered with dry ether $(2 \mathrm{~mL})$ and the tube was left closed for one week, to provide (2) $\bullet \mathrm{Ph}_{4} \mathrm{PCl}$ as slightly orange crystals. Good elemental analysis could not be obtained probably due to contamination with the hydrated form.

2•( $\left(\mathrm{Ph}_{4} \mathrm{PBr}\right)_{2}$. Same procedure as above with $2(14.6 \mathrm{mg}, 0.026 \mathrm{mmol})$ and $\mathrm{Ph}_{4} \mathrm{PBr}(22.6$ $\mathrm{mg}, 0.054 \mathrm{mmol}, 2$ equiv). Good elemental analysis could not be obtained probably due to contamination with the hydrated form.

2• $\left(\mathrm{Ph}_{4} \mathrm{PCl}\right)_{2} \bullet\left(\mathrm{H}_{2} \mathrm{O}\right)_{2}$. Same procedure as above from $2(16.7 \mathrm{mg}, 0.03 \mathrm{mmol})$ and $\mathrm{Ph}_{4} \mathrm{PCl}$ (22.4mg, $0.059 \mathrm{mmol}, 2$ equiv), but with one drop of demineralized water added to benzonitrile. M. p. $153^{\circ} \mathrm{C}$ (decomp.) Elem. Anal. Calcd for $\mathbf{2} \bullet\left(\mathrm{Ph}_{4} \mathrm{PBr}\right)_{2} \bullet\left(\mathrm{H}_{2} \mathrm{O}\right)_{2}\left(\mathrm{C}_{62} \mathrm{H}_{54} \mathrm{Cl}_{2} \mathrm{~N}_{4} \mathrm{O}_{2} \mathrm{P}_{2} \mathrm{Se}_{4}, \mathrm{MW}=\right.$ 1335.83 g/mol): C, 55.75; H, 4.07; N, 4.19\%. Found C, 55.84, H, 4.09, N, 4.08\%.

$\mathbf{2} \cdot\left(\mathrm{Ph}_{4} \mathrm{PBr}\right)_{2} \bullet\left(\mathrm{H}_{2} \mathrm{O}\right)_{2}$. Same procedure as above from $2(10.7 \mathrm{mg}, 0.019 \mathrm{mmol})$ and $\mathrm{Ph}_{4} \mathrm{PBr}$ (16.4mg, $0.039 \mathrm{mmol}, 2$ equiv) but with one drop of demineralized water added to benzonitrile. M. p. 171 (decomp). Elem. Anal. Calcd for $2 \bullet\left(\mathrm{Ph}_{4} \mathrm{PBr}\right)_{2} \bullet\left(\mathrm{H}_{2} \mathrm{O}\right)_{2}\left(\mathrm{C}_{62} \mathrm{H}_{54} \mathrm{Br}_{2} \mathrm{~N}_{4} \mathrm{O}_{2} \mathrm{P}_{2} \mathrm{Se}_{4}, \mathrm{MW}=\right.$ 1424.74 g/mol): C, 52.27; H, 3.82; N, 3.93\%. Found C, 52.42, H, 3.73, N, 3.85\%. 
$(\mathbf{1})_{2} \bullet \mathrm{Ph}_{4} \mathrm{PCl} \bullet \mathrm{Et}_{2} \mathrm{O} . \mathbf{1}(0.0208 \mathrm{~g})$ was dissolved in EtOAc. $\mathrm{Ph}_{4} \mathrm{PCl}(0.0119 \mathrm{~g})$ was added to the EtOAc solution of $\mathbf{1}$, a couple drops of $\mathrm{MeOH}$ were added for solubility of the phosphonium salt. Vapor diffusion of ether into the salt solution precipitated white crystals. M. p. $126-127^{\circ} \mathrm{C}$ (with color change from light orange to gray at $118-120^{\circ} \mathrm{C}$ ). Elem. Anal. Calcd for $(\mathbf{1})_{2} \bullet \mathrm{Ph}_{4} \mathrm{PCl}$ $\left(\mathrm{C}_{44} \mathrm{H}_{36} \mathrm{ClN}_{4} \mathrm{PSe}_{4}, \mathrm{MW}=1003.0634 \mathrm{~g} / \mathrm{mol}\right): \mathrm{C}, 52.69 ; \mathrm{H}, 3.62 ; \mathrm{N}, 5.59 \%$. Found $\mathrm{C}, 53.30, \mathrm{H}, 3.70$, $\mathrm{N}, 5.32 \%$

$(\mathbf{1})_{2} \cdot \mathrm{Ph}_{4} \mathrm{PBr} .1$ (0.0193 g) was dissolved in EtOAc. $\mathrm{Ph}_{4} \mathrm{PBr}(0.0128 \mathrm{~g})$ was added to the EtOAc solution of $\mathbf{1}$, a couple drops of $\mathrm{MeOH}$ were added for solubility of the phosphonium salt. Vapor diffusion of ether into the salt solution precipitated white crystals. M. p. $133-134{ }^{\circ} \mathrm{C}$ (with color change from white to gray at $\left.100-110^{\circ} \mathrm{C}\right)$. Elem. Anal. Calcd for $(\mathbf{1})_{2} \bullet \mathrm{Ph}_{4} \mathrm{PBr}$ $\left(\mathrm{C}_{44} \mathrm{H}_{36} \mathrm{BrN}_{4} \mathrm{PSe}_{4}, \mathrm{MW}=1047.5144 \mathrm{~g} / \mathrm{mol}\right): \mathrm{C}, 50.45 ; \mathrm{H}, 3.46 ; \mathrm{N}, 5.35 \%$. Found: $\mathrm{C}, 50.53, \mathrm{H}$, $3.35, \mathrm{~N}, 5.35 \%$.

$\mathbf{2} \cdot \mathrm{Bu}_{4} \mathrm{NCl}$ and $\mathbf{2} \cdot \mathrm{Bu}_{4} \mathrm{NCl} \bullet(\mathrm{PhCN})_{0.5}$. In a small tube, $\mathbf{2}(9.5 \mathrm{mg}, 0.017 \mathrm{mmol}, 1$ equiv) and $n$-Bu ${ }_{4} \mathrm{NCl}\left(9.7 \mathrm{mg}, 0.034 \mathrm{mmol}, 2\right.$ equiv) was dissolved with $2 \mathrm{~mL}$ of dry benzonitrile at $60^{\circ} \mathrm{C}$ and the solution layered with dry ether $(2 \mathrm{~mL})$. The tube was tightly closed, and crystals were obtained after one week, as a mixture of the two polymorphs. The intimate mixture hindered elemental analysis or m.p. determination.

Crystallography. Data were collected on an APEXII, Bruker-AXS diffractometer operating with graphite-monochromated Mo-K $\alpha$ radiation $(\lambda=0.71073 \AA)$, or on D8 VENTURE Bruker AXS diffractometer at $150 \mathrm{~K}$, operating with graphite-monochromated Mo-K $\alpha$ radiation $(\lambda=0.71073 \AA)$ or $\mathrm{Cu}$ - K $\alpha$ radiation $(\lambda=1.54184 \AA)$. The structures were solved by direct methods using the SIR92 program, ${ }^{54}$ and then refined with full-matrix least-square methods based on $F^{2}$ (SHELXL-2014/7) $)^{55}$ with the aid of the WINGX program. ${ }^{56}$ All non-hydrogen atoms were refined with anisotropic atomic displacement parameters. $\mathrm{H}$ atoms were finally included in their calculated positions. Crystallographic data on X-ray data collection and structure refinements are given in Table S3. CCDC 1865831-1865840 contains the supplementary crystallographic data for this paper. 
Theoretical calculations. DFT calculations were performed with the following conditions, with B3LYP functional, 6-31+G** basis set for $\mathrm{C}, \mathrm{H}, \mathrm{N}, \mathrm{F}$ and Br, LANDL2Ddp ECP basis set for Se and I, downloaded from the EMSL database. ${ }^{57,58}$ Geometry optimization (See Table S4 in ESI for details) was performed for all neutral compounds $\mathrm{C}_{6} \mathrm{~F}_{5}-\mathrm{I}, \mathrm{BzSeCN}$, syn-1, anti-1, and anti$\mathbf{2}$, with the exception of syn-2 which is not an energy minimum, and the ESP were computed on the 0.001 a.u. isodensity surfaces. Geometrical optimizations of the $\mu_{4}-\mathrm{X}^{-}$molecular structure found in $(\mathbf{1})_{2} \cdot \mathrm{Ph} 4 \mathrm{PCl}$ and $(\mathbf{1})_{2} \bullet \mathrm{Ph}_{4} \mathrm{PBr}$ were performed in the same conditions.

\section{ASSOCIATED CONTENT}

Supporting Information

The Supporting Information is available free of charge on the ACS Publications website at DOI: 10.1021/XXX. Pdf file (8 pages) with Figures S1-S5, Tables S1-S4. Crystallographic files in cif format.

Accession Codes CCDC 1865831-1865840 contains the supplementary crystallographic data for this paper. These data can be obtained free of charge via www.ccdc.cam.ac.uk/data_request/cif, or by emailing data_request@ccdc.cam.ac.uk, or by contacting The Cambridge Crystallographic Data Centre, 12, Union Road, Cambridge CB2 1EZ, UK; fax: +44 1223336033.

\section{AUTHOR INFORMATION}

Corresponding Author

*marc.fourmigue@univ-rennes1.fr

ORCID

Marc Fourmigué https://orcid.org/0000-0002-3796-4802

Orion Berryman https://orcid.org/0000-0002-0324-484X

\section{Notes}

The authors declare no competing financial interest.

\section{ACKNOWLEDGMENTS}

Financial supports from (i) ANR (Paris, France) through contract ANR-17-CE07-0025-02, (ii) Rennes Métropole (Decision A17.612) and (iii) the Chateaubriand Fellowship of the Office for 
Science \& Technology of the Embassy of France in the United States are acknowledged. We also thank CDIFX (Rennes) for access to X-ray diffraction facilities. This work was also partially funded by the National Science Foundation (NSF) CAREER CHE-1555324.

\section{REFERENCES}

${ }^{1}$ Cavallo, G.; Metrangolo, P.; Milani, R.; Pilati, T.; Priimagi, A.; Resnati, G.; Terraneo, G. The Halogen Bond. Chem. Rev. 2016, 116, 2478-2601.

2 Gilday, L.C.; Robinson, S.W.; Barendt, T.A.; Langton, M.J.; Mullaney, B.R.; Beer, P.D. Halogen Bonding in Supramolecular Chemistry. Chem. Rev. 2015, 115, 7118-7195.

${ }^{3}$ Cavallo, G.; Metrangolo, P.; Pilati, T.; Resnati, G.; Terraneo, G. Naming Interactions from the Electrophilic Site. Cryst. Growth Des. 2014, 14, 2697-2702

4 Terraneo, G. ; Resnati, G. Bonding Matters. Cryst. Growth Des. 2017, 17, 1439-1440

5 Wang, W.; Ji, B.; Zhang, Y. Chalcogen Bond: A Sister Noncovalent Bond to Halogen Bond. J. Phys. Chem. A 2009, 113, 8132-8135.

${ }^{6}$ Alkorta, I.; Elguero, J.; Del Bene, J. E. A Computational Study of Chalcogen-containing $\mathrm{H}_{2} \mathrm{X} \ldots \mathrm{YF}$ and $\left(\mathrm{CH}_{3}\right)_{2} \mathrm{X} \ldots \mathrm{YF}(\mathrm{X}=\mathrm{O}, \mathrm{S}, \mathrm{Se} ; \mathrm{Y}=\mathrm{F}, \mathrm{Cl}, \mathrm{H})$ and Pnictogen-containing $\mathrm{H}_{3} \mathrm{X}^{\prime} \ldots \mathrm{YF}$ and $\left(\mathrm{CH}_{3}\right)_{3} \mathrm{X}^{\prime} \ldots \mathrm{YF}\left(\mathrm{X}^{\prime}=\mathrm{N}, \mathrm{P}, \mathrm{As}\right)$ Complexes. ChemPhysChem 2018 , DOI:10.1002/cphc.201800179.

${ }^{7}$ Bleiholder, C; Werz, D. B.; Koppel, H; Gleiter, R. Theoretical Investigations on Chalcogen-Chalcogen Interactions: What Makes These Nonbonded Interactions Bonding? J. Am. Chem. Soc. 2006, 128, 2666-2674.

8 Politzer, P.; Murray, J. S.; Clark, T.; Resnati, G. The $\sigma$-hole revisited. Phys. Chem. Chem. Phys. 2017, 19, 32166-32178.

${ }^{9}$ Bent, H. A. Structural chemistry of donor-acceptor interactions. Chem. Rev. 1968, 68, 587648.

${ }^{10}$ Klapötke, T. M.; Krumm, B.; Scherr, M. Homoleptic Selenium Cyanides: Attempted Preparation of $\mathrm{Se}(\mathrm{CN})_{4}$ and Redetermination of the Crystal Structure of $\mathrm{Se}(\mathrm{CN})_{2}$. Inorg. Chem. 2008, 47, 7025-7028. 
${ }^{11}$ Klapötke, T. M.; Krumm, B.; Gálvez-Ruiz, J. C.; Nöth, H.; Schwab, I. Experimental and Theoretical Studies of Homoleptic Tellurium Cyanides $\mathrm{Te}(\mathrm{CN})_{\mathrm{x}}$ : Crystal Structure of $\mathrm{Te}(\mathrm{CN})_{2}$. Eur. J. Inorg. Chem. 2004, 4764-4769.

12 Ho, P. C.; Szydlowski, P.; Sinclair, J.; Elder, P. J. W.; Kübel, J.; Gendy, C.; Lee, L. M.; , Jenkins, H.; Britten, J. F.; Morim, D.; Vargas-Baca, I. Supramolecular macrocycles reversibly assembled by Te...O chalcogen bonding. Nature Comm. 2016, 7, 11299.

${ }^{13}$ Cozzolino, A. F.; Whitfield, P. S.; Vargas-Baca, I. Supramolecular Chromotropism of the Crystalline Phases of 4,5,6,7-Tetrafluorobenzo-2,1,3-telluradiazole. J. Am. Chem. Soc., 2010, 132, 17265-17270.

${ }^{14}$ Brezgunova, M.; Lieffrig, J.; Aubert, E.; Dahaoui, S.; Fertey, P.; Lebègue, S.; Angyan, J.; Fourmigué, M.; Espinosa, E. Chalcogen Bonding: Experimental and Theoretical Determinations from Electron Density Analysis. Geometrical Preferences Driven by Electrophilic-Nucleophilic Interactions. Cryst. Growth Des. 2013, 13, 3283-3289.

15 Jeannin, O.; Huynh, H.-T.; Riel, A. M. S.; Fourmigué, M. Chalcogen bonding interactions in organic selenocyanates: from cooperativity to chelation. New J. Chem. 2018, 42, 1050210509.

16 Huynh, H.-T.; Jeannin, O.; Fourmigué, M. Organic selenocyanates as strong and directional chalcogen bond donors for crystal engineering. Chem. Commun. 2017, 53, 8467-8469

${ }^{17}$ Walsh, R. B.; Padgett, C. W.; Metrangolo, P.; Resnati, G.; Hanks, T. W.; Pennington, W. T. Crystal Engineering through Halogen Bonding: Complexes of Nitrogen Heterocycles with Organic Iodides. Cryst. Growth Des. 2001, 1, 165-175.

${ }^{18}$ Metrangolo, P.; Meyer, F.; Pilati, T.; Resnati, G.; Terraneo, G. 4,4'-Bi-pyridine-2,4,5,6tetra-fluoro-1,3-di-iodo-benzene (1/1). Acta Crystallogr. 2007, E63, o4243.

${ }^{19}$ Mati, S. S.; Roy, S. S.; Chall, S.; Bhattacharya, S.; Bhattacharya, S. C. Unveiling the Groove Binding Mechanism of a Biocompatible Naphthalimide-Based Organoselenocyanate with Calf Thymus DNA: An "Ex Vivo" Fluorescence Imaging Application Appended by Biophysical Experiments and Molecular Docking Simulations. J. Phys. Chem. B. 2013, 117, $14655-14665$.

${ }^{20}$ Facompre, N. D.; El-Bayoumy, K.; Sun Y. W.; Pinto J. T.; Sinha R. 1,4-Phenylenebis(Methylene)Selenocyanate, but Not Selenomethionine, Inhibits Androgen Receptor and Akt Signaling in Human Prostate Cancer Cells. Cancer Prev. Res. 2010, 3, 975-984. 
${ }^{21}$ Plano, D.; Baquedano, Y.; Moreno-Mateos, D.; Font, M.; Jiménez-Ruiz, A.; Palop, J. A.; Sanmartìn, C. Selenocyanates and diselenides: a new class of potent antileishmanial agents. Eur. J. Med. Chem. 2011, 46, 3315-3323.

${ }^{22}$ Cavallo, G.; Metrangolo, P.; Pilati, T.; Resnati, G.; Sansotera, M.; Terraneo, G. Halogen bonding: a general route in anion recognition and coordination. Chem. Soc. Rev. 2010, 39, 3772-3783.

${ }^{23}$ Metrangolo, P.; Meyer, F.; Pilati, T.; Resnati, G.; Terraneo, G. Halogen Bonding in Supramolecular Chemustry. Angew. Chem. Int. Ed. 2008, 47, 6114-6127.

${ }^{24}$ Lieffrig, J.; Jeannin, O.; Frąckowiak, A.; Olejniczak, I.; Świetlik, R.; Dahaoui, S.; Aubert, E.; Espinosa, E.; Auban-Senzier, P.; Fourmigué, M. Charge-Assisted Halogen Bonding: DonorAcceptor Complexes with Variable Ionicity. Chem. Eur. J. 2013, 19, 14804-14813.

${ }^{25}$ Riel, A. M. S.; Decato, D. A.; Sun, J.; Massena, C. J.; Jessop, M. J.; Berryman, O. B. The intramolecular hydrogen bonded-halogen bond: a new strategy for preorganization and enhanced binding. Chem. Sci. 2018, 9, 5828-5836.

${ }^{26}$ Wageling, N. B.; Neuhaus, G. F.; Rose, A. M.; Decato, D. A.; Berryman, O. B. Advantages of organic halogen bonding for halide recognition. Supramol. Chem. 2016, 28, 665-672.

${ }^{27}$ Massena, C. J.; Wageling, N. B.; Decato, D. A.; Martin Rodriguez, E.; Rose, A. M.; Berryman, O. B. A Halogen-Bond-Induced Triple Helicate Encapsulates Iodide. Angew. Chem. Intl. Ed., 2016, 55, 12398-12402.

${ }^{28}$ Fourmigué, M. Coordination chemistry of anions through halogen-bonding interactions. Acta Cryst. 2017, B73, 138-139.

${ }^{29}$ Lieffrig, J.; Jeannin, O.; Fourmigué, M. Expanded Halogen-Bonded Anion Organic Networks with Star-Shaped Iodoethynyl-Substituted Molecules: From Corrugated 2D Hexagonal Lattices to Pyrite-Type 2-Fold Interpenetrated Cubic Lattices. J. Am. Chem. Soc. 2013, 135, $6200-6210$.

${ }^{30}$ Viger-Gravel, J.; Leclerc, S.; Korobkov, I.; Bryce, D. L. Correlation between ${ }^{13} \mathrm{C}$ chemical shifts and the halogen bonding environment in a series of solid para-diiodotetrafluorobenzene complexes. CrystEngComm 2013, 15, 3168-3177.

${ }^{31}$ Szell, P. M. J.; Cavallo, G.; Terraneo, G.; Metrangolo, P.; Gabidullin, B.; Bryce, D. L. Comparing the Halogen Bond to the Hydrogen Bond by Solid-State NMR Spectroscopy: 
Anion Coordinated Dimers from 2- and 3-Iodoethynylpyridine Salts. Chem. Eur. J. 2018, 24, 11364-11376.

${ }^{32}$ Szell, P. M. J.; Gabidullin, B.; Bryce, D. L. 1,3,5-Tri(iodoethynyl)-2,4,6-tri-fluoro-benzene: halogen-bonded frameworks and NMR spectroscopic analysis. Acta Cryst. B, 2017, 73, $153-$ 162.

${ }^{33}$ Schmidt, B.; Sonnenberg, K.; Beckers, H.; Steinhauser, S.; Riedel, S. Synthesis and Characterization of Nonclassical Interhalides Based on Bromine Monochloride. Angew. Chem. Int. Ed. 2018, 57, 9141-9145.

34 Garrett, G. E.; Carrera, E. I.; Seferos, D. S.; Taylor, M. S. Anion recognition by a bidentate chalcogen bond donor. Chem. Commun. 2016, 52, 9881-9884.

${ }^{35}$ Garrett, G. E.; Gibson, G. L.; Straus, R. N.; Seferos, D. S.; Taylor, M. S. Chalcogen Bonding in Solution: Interactions of Benzotelluradiazoles with Anionic and Uncharged Lewis Bases. $J$. Am. Chem. Soc. 2015, 137, 4126-4133.

${ }^{36}$ Scheiner, S. Highly Selective Halide Receptors Based on Chalcogen, Pnicogen, and Tetrel Bonds. Chem. Eur. J. 2016, 22, 18850-18858.

${ }^{37}$ Scheiner, S. Comparison of halide receptors based on $\mathrm{H}$, halogen, chalcogen, pnicogen, and tetrel bonds. Faraday Discuss. 2017, 203, 213-226.

${ }^{38}$ Benz, S.; Macchione, M.; Verolet, Q.; Mareda, J.; Sakai, N.; Matile, S. Anion Transport with Chalcogen Bonds. J. Am. Chem. Soc. 2016, 138, 9093-9096.

${ }^{39}$ Sánchez-Sanz, G.; Trujillo, C. Improvement of Anion Transport Systems by Modulation of Chalcogen Interactions: The influence of solvent. J. Phys. Chem. A 2018, 122, 1369-1377.

${ }^{40}$ Macchione, M.; Tsemperouli, M.; Goujon, A.; Mallia, A. R.; Sakai, N.; Sugihara, K.; Matile, S. Mechanosensitive Oligodithienothiophenes: Transmembrane Anion Transport Along Chalcogen-Bonding Cascades. Helv. Chim. Acta 2018, 101, e1800014.

${ }^{41}$ Lim, J. Y. C.; Marques, I.; Thompson, A. L.; Kirsten E. Christensen, K. E.; Félix, V., Beer, P. D. Chalcogen Bonding Macrocycles and [2]Rotaxanes for Anion Recognition. J. Am. Chem. Soc. 2017, 139, 3122-3133.

${ }^{42}$ Benz, B.; Lopez-Andarias, J.; Mareda, J.; Sakai, N. Matile, S. Catalysis with Chalcogen Bonds. Angew. Chem. Int. Ed. 2017, 56, $812-815$. 
${ }^{43}$ Benz, S.; Mareda, J.; Besnard, C.; Sakai, N; Matile, S. Catalysis with chalcogen bonds: neutral benzodiselenazole scaffolds with high-precision selenium donors of variable strength. Chem. Sci. 2017, 8, 8164-8169

${ }^{44}$ Wonner, P.; Vogel, L.; Düser, M.; Gomes, L.; Kniep, F.; Mallick, B.; Werz, D. B.; Huber, S. M. Carbon-Halogen Bond Activation by Selenium-Based Chalcogen Bonding. Angew. Chem. Int. Ed. 2017, 56, $12009-12012$.

${ }^{45}$ Wonner, P.; Vogel, L.; Kniep, F.; Huber, S. M. Catalytic Carbon-Chlorine Bond Activation by Selenium-Based Chalcogen Bond Donors. Chem. Eur. J. 2017, 23, 16972-16975.

${ }^{46}$ Hauge, S.; Maroy, K. Reactions between Selenocyanate and Bromine. Syntheses and Crystal Structures of Phenyltrimethylammonium Salts of Dibromoselenocyanate, $\left[\mathrm{C}_{6} \mathrm{H}_{5}\left(\mathrm{CH}_{3}\right)_{3} \mathrm{~N}\right]\left[\mathrm{SeCNBr}_{2}\right]$, and Bromodiselenocyanate, $\left[\mathrm{C}_{6} \mathrm{H}_{5}\left(\mathrm{CH}_{3}\right)_{3} \mathrm{~N}\right]\left[(\mathrm{SeCN})_{2} \mathrm{Br}\right]$. Acta Chem. Scand. 1992, 46, 1166-1169.

${ }^{47}$ Semenov, N. A.; Gorbunov, D. E.; Shakhova, M. V.; Salnikov, G. E.; Bagryanskaya, I. Y.; Korolev, V. V.; Beckmann, J.; Gritsan, N. P.; Zibarev, A. V. Donor-Acceptor Complexes between 1,2,5-Chalcogenadiazoles (Te, Se, $\mathrm{S})$ and the Pseudohalides $\mathrm{CN}^{-}$and $\mathrm{XCN}^{-}(\mathrm{X}=\mathrm{O}$, S, Se, Te). Chem. Eur. J. 2018, 24, 12983-12991.

${ }^{48}$ Kumar, V; Leroy, C.; Bryce, D. L. Halide ion recognition via chalcogen bonding in the solid state and in solution. Directionality and linearity. CrystEngComm 2018, 20, 6406-6411.

${ }^{49}$ Cirera, J.; Alemany, P.; Alvarez, S. Mapping the Stereochemistry and Symmetry of Tetracoordinate Transition-Metal Complexes. Chem. Eur. J. 2004, 10, 190-207.

${ }^{50}$ Alvarez, S.; Alemany, P.; Casanova, D.; Cirera, J.; Llunell, M.; Avnir, D. Shape Maps and Polyhedral Interconversion Paths in Transition Metal Chemistry. Coord. Chem. Rev. 2005, 249, 1693-1708.

${ }^{51}$ Hynes, M. J. EQNMR: a computer program for the calculation of stability constants from nuclear magnetic resonance chemical shift data. J. Chem. Soc., Dalton Trans. 1993, 311-312.

${ }^{52}$ Lim, J. Y. C.; Liew, J. Y. Beer, P. D. Thermodynamics of Anion Binding by Chalcogen Bonding Receptors. Chem. Eur. J. 2018, 24, 14560-14566.

${ }^{53}$ McWhinnie, S. L. W.; Brooks, A. B.; Abrahams, I. $\alpha \alpha$-Di-seleno-cyanato-ortho-xylene. Acta Cryst. $C, \mathbf{1 9 9 8}, 54,126-128$. 
${ }^{54}$ Altomare, A.; Cascarano, G.; Giacovazzo, C.; Guagliardi, A.; Burla, M. C.; Polidori, G.;

Camalli, M. SIR92 - a program for automatic solution of crystal structures by direct methods. J. Appl. Cryst. 1994, 27, 435-436.

${ }^{55}$ Sheldrick, G. M. Crystal structure refinement with SHELXL. Acta Cryst. C, 2015, 71, 3-8.

${ }^{56}$ Farrugia, L. J. WinGX and ORTEP for Windows: an update. J. Appl. Cryst. 2012, 45, 849-854.

${ }^{57}$ Feller, D. The role of databases in support of computational chemistry calculations. J. Comp. Chem. 1996, 17, 1571-1586.

${ }^{58}$ Schuchardt, K.L., Didier, B.T., Elsethagen, T., Sun, L., Gurumoorthi, V., Chase, J., Li, J., and Windus, T.L. Basis set exchange: a community database for computational sciences. J. Chem. Inf. Model. 2007, 47, 1045-1052. 


\section{Organic selenocyanates as halide receptors: from chelation to one- dimensional systems}

Asia Marie S. Riel,,${ }^{\dagger \neq}$ Huu-Tri Huynh, ${ }^{\dagger}$ Olivier Jeannin, ${ }^{\dagger}$ Orion Berryman, ${ }^{\ddagger}$ and Marc Fourmigué $*, \dagger$

${ }^{\dagger}$ Univ Rennes, CNRS, ISCR (Institut de Sciences Chimiques de Rennes), UMR 6226, 35000 Rennes, France

$¥$ Department of Chemistry and Biochemistry, University of Montana, 32 Campus Dr., Missoula MT 59812, USA

\section{For Table of Contents Use Only}

Ortho-substituted bis(selenocyanatomethyl)benzene derivatives act as efficient chelating agents for halides through short and directional Se $\bullet \mathrm{X}^{-}$chalcogen bonding $(\mathrm{ChB})$ interactions. Crystal structures of $\mu_{2}$-halide and $\mu_{4}$-halide motifs are analyzed, together with complementary ${ }^{1} \mathrm{H}$ solution NMR studies and theoretical calculations.

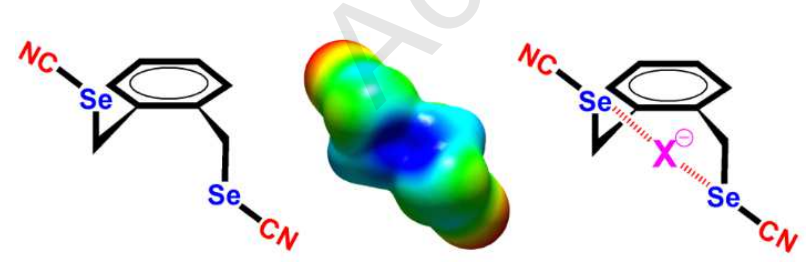

